\title{
Estimasi Nilai Ekonomi Obat Tidak Digunakan pada Kalangan Rumah Tangga Kota Yogyakarta
}

\author{
Economic Value Estimation of Unused Medicines Among Households in Yogyakarta City
}

Bai Athur Ridwan*, Susi Ari Kristina, Chairun Wiedyaningsih

Fakultas Farmasi Universitas Gadjah Mada, Yogyakarta.

Submitted: 1-24-2019 Revised: 6-10-2019

Accepted: 8-8-2019

Korespondensi : Bai Athur Ridwan : Email : baiathurridwan05@gmail.com

\begin{abstract}
ABSTRAK
Semua tipe obat yang disimpan tanpa niat untuk digunakan lagi, dikembalikan ke apotek, tenaga profesi kesehatan, dibuang ke tempat pengumpulan obat atau melalui sampah rumah tangga dapat dianggap sebagai limbah obat. Pasien mungkin tidak dapat menggunakan semua obat yang diperoleh dari pengobatan karena perubahan dosis atau obat-obat yang telah kedaluwarsa. Hal ini diperkirakan memiliki konsekuensi terhadap finansial. Tujuan utama dari penelitian ini adalah untuk mengetahui nilai ekonomi obat tidak digunakan dan kedaluwarsa pada kalangan rumah tangga Kota Yogyakarta.Penelitian ini berupa observatif dengan rancangan studi cross sectional. Responden dipilih secara convenience sampling dan diwawancara langsung serta mendata obat-obat yang disimpan di rumah. Data dianalisis dan dipersentasikan secara deskriptif.Dari 400 responden, hanya 261 (65,2\%) yang menyimpan obat terdiri dari obat sedang digunakan dan persediaan, obat tidak digunakan dan obat kedaluwarsa dengan total harga sebesar Rp7.082.556. Total harga obat tidak digunakan sebesar Rp1.273.921 (18\%) dengan ratarata Rp13.698 per orang sedangkan obat kedaluwarsa hanya berharga Rp140.065 (2\%) dengan rata-rata Rp12.733. Berdasarkan kelas terapi, jumlah obat tidak digunakan paling banyak adalah analgesik (28,6\%), sistem respirasi $(13,7 \%)$, dan antimikroba $(11,9 \%)$, sedangkan obat kedaluwarsa utamanya analgesik, saluran cerna dan antiseptik masing-masing (18,8\%). Nilai rata-rata ekonomi obat tidak digunakan dan kedaluwarsa per orang jika diakumulasi berdasarkan riset kesehatan dasar tahun 2013 dengan 48.814 rumah tangga yang menyimpan obat sisa maka nilai ekonomi obat yang bisa dihemat yaitu sebesar Rp668.654.172. Penelitian ini dapat berfungsi dalam program edukasi masyarakat untuk meningkatkan kepatuhan dan penggunaan obat secara tepat dan efisien agar dapat dilakukan penghematan biaya kesehatan yang dikeluarkan.
\end{abstract}

Kata kunci: obat tidak digunakan; obat kedaluwarsa; biaya

\section{ABSTRACT}

Expenditures for prescription drugs and over-the-counter drugs constitute a large percentage of the total health care costs. Patients may not be able to use all drugs obtained from treatment because of changes in dosage or drugs that have expired. This is thought to have financial consequences. The main purpose of this study was to find out the economic value of unused medicines and expired in the Yogyakarta city household.This research was observational with cross-sectional study design. Respondents were selected by convenience sampling and interviewed directly and the drugs stored at home were recorded. Data were analyzed and presented descriptively.Of the 400 respondents, only $261(65.2 \%)$ stored drugs consisted of drugs being used and supplies, drugs not used and drugs expired with a total price of Rp7,082,556. The total price of unused drugs amounted to 1.273 .921 IDR (18\%) with an average of 13.698 IDR per person while the expired drugs only cost 140.065 IDR (2\%) with an average of 12.733 IDR. Based on therapeutic class, the highest number of drugs not used were analgesics (28.6\%), respiration system (13.7\%), and antimicrobial (11.9\%), while expired drugs were mainly analgesics, gastrointestinal tract and antiseptic respectively (18.8\%). The average economic value of the drug is not used and expires per person if it is accumulated based on basic health research in 2013 with 48,814 households storing remnants of the drug so that the economical value of the drug that can be saved is Rp.668,654,172. This research can be appliedin public education programs to improve compliance and use of drugs appropriately and efficiently so that savings can be made on the health costs incurred.

Keywords: drugs unused; expired drugs; costs 


\section{PENDAHULUAN}

Semua tipe obat yang disimpan tanpa niat untuk digunakan lagi, dikembalikan ke apotek, tenaga profesi kesehatan, dibuang ke tempat pengumpulan obat atau melalui sampah rumah tangga dapat dianggap sebagai limbah obat. ${ }^{1}$ Pasien mungkin tidak dapat menggunakan semua obat yang diperoleh dari pengobatan karena perubahan dosis atau obat-obat yang telah kedaluwarsa. ${ }^{2}$ Selain itu, obat-obat yang tidak digunakan bisa muncul dari rumah tangga atau aktivitas layanan kesehatan. ${ }^{3}$ tujuan pelayanan kesehatan adalah untuk meningkatkan status kesehatan pasien melalui alokasi sumber daya perawatan kesehatan yang optimal namun beberapa faktor seperti sisa obat karena ketidak patuhan pasien dalam penggunaan obat, praktik promosi oleh produsen, praktik resep dokter atau praktik dispensing dapat berkontribusi terhadap adanya limbah obat di masyarakat yang dibuang tanpa pengelolaan sesuai standar misalnya dibuang ke tempat sampah, saluran air, atau toilet sehingga berdampak terhadap lingkungan dan kesehatan. ${ }^{3-5}$ pengelolaan limbah medis yang buruk dapat mengakibatkan infeksi, efek toksik, dan cedera pada petugas kesehatan, pekerja limbah, dan masyarakat. Selain itu juga, dapat berpotensi terhadap penyebaran resistensi mikroorganisme ke lingkungan. ${ }^{6}$ Pembuangan obat juga menyumbang proporsi besar terhadap biaya perawatan kesehatan yang semakin meningkat di seluruh dunia. ${ }^{7}$ Hal ini menggambarkan hilangnya kesempatan untuk meningkatkan kesehatan pada pasien yang terlibat dalam pemborosan biaya kesehatan yang seharusnya bisa digunakan untuk membiayai perawatan kesehatan yang sangat dibutuhkan. ${ }^{5}$ Berdasarkan analisis studi lebih lanjut tentang obat-obatan yang tidak digunakan menunjukkan implikasi ekonomi yang tinggi bagi pembayar, mungkin juga ada biaya tidak langsung karena efektivitas yang terbatas dan kegagalan terapi, efek yang tidak diinginkan dari penggunaan obat yang salah sehingga pada akhirnya berdampak negatif pada morbiditas dan mortalitas. ${ }^{1}$
Limbah medis termasuk obat tidak digunakan atau kedaluwarsa diperkirakan memiliki konsekuensi terhadap finansial. Sebagaimana penelitian di New zeland, dilaporkan bahwa total biaya obat tidak digunakan yang dikembalikan bernilai $\$ 23.590$ dan obat kedaluwarsa bernilai $\$ 14.500$ dari 163 responden. ${ }^{5}$ Selain itu, penelitian yang dilakukan di Kalifornia selatan Amerika Serikat menemukan bahwa obat tidak digunakan bernilai $\$ 152.014,89$ berdasarkan Average Wholesale Price (AWP). ${ }^{8}$ Penelitian lain yang dilakukan di Jordania pada kalangan rumah tangga melaporkan bahwa dari 2835 total item obat yang ditemukan terdapat $34,7 \%$ obat tidak digunakan dengan estimasi total nilai 6.326.000 JD dan 5,8\% obat telah kedaluwarsa dengan nilai 1.267.000 JD. ${ }^{9}$

Penanganan terhadap limbah obat seperti pengumpulan atau pengembalian obat ke fasilitas kesehatan dan pembuatan regulasi telah dilakukan oleh beberapa negara yaitu Australia, Brazil, Canada, Colombia, Egypt, Lebanon, Saudi arabia, USA, dan UK sebagai upaya meminimalkan dampak negatif terhadap kesehatan, lingkungan, dan pemborosan biaya dari obat yang tidak digunakan.10,11 Namun sayangnya, biaya obatobat tidak digunakan di Indonesia masih kurang menjadi perhatian dan dasar evaluasi terhadap kerugian biaya perawatan kesehatan yang dikeluarkan oleh pasien atau masyarakat. Berdasarkan hal ini maka apoteker dapat berperan penting dalam memberikan edukasi tentang penggunaan obat secara tepat. Salah satu pendekatan untuk menangani masalah tersebut adalah dengan memastikan penggunaan obat seefisien mungkin dan meminimalkan potensi obat tidak digunakan atau pemborosan obat. ${ }^{12}$ Tujuan utama dari penelitian ini adalah untuk mengetahui nilai ekonomi obat tidak digunakan dan kedaluwarsa pada kalangan rumah tangga Kota Yogyakarta. Studi ini juga dapat berfungsi untuk pelaksanaan program edukasi kepada masyarakat untuk meningkakan kesadaran terkait penggunaan obat secara tepat. 


\section{METODE}

Penelitian ini menggunakan desain observatif yang dilakukan dengan rancangan studi cross sectional pada kalangan rumah tangga Kota Yogyakarta. Populasi rumah tangga di Kota Yogyakarta Provinsi Daerah Istimewa Yogyakarta berjumlah 127.960 rumah tangga ${ }^{13}$ dan jumlah sampel ditentukan berdasarkan rumus Slovin ${ }^{14}$, dengan tingkat kesalahan 5\%, dengan rumus:

$$
\mathrm{n}=\frac{\mathrm{N}}{1+\mathrm{N} \alpha^{2}}
$$

keterangan: $\mathrm{n}=$ ukuran sampel; $\mathrm{N}=$ ukuran populasi; $\alpha=$ taraf signifikansi, yaitu 0,05 atau $5 \%$

Berdasarkan perhitun gan diperoleh jumlah sampel minimal 399 rumah tangga. Target responden dipilih berdasarkan metode convenience sampling yang bertempat tinggal di lima Kecamatan Kota Yogyakarta yaitu Kecamatan Gondokusuman, Kecamatan Jetis, Kecamatan Tegalrejo, Kecamatan Margangsan, dan Kecamatan Danurejan. Anggota rumah tangga yang berada dirumah selama periode penelitian antara bulan JuliSepetember 2018 dengan batas usia $\geq 17$ tahun dan bersedia untuk diwawancara masuk sebagai responden penelitian, sedangkan anggota rumah tangga yang memiliki keterbatasan fisik atau gangguan mental dan rumah tangga yang datang $<1$ bulan di Kota Yogyakarta tidak termasuk sebagai responden dalam penelitian ini. Hasil penelusuran di lokasi penelitian, diperoleh 400 responden rumah tangga.

Pengumpulan data dilakukan dengan menggunakan alat ukur kuesioner yang dikembangkan berdasarkan kajian literatur yang disesuaikan dengan konteks lokal berupa pertanyaan tertutup yang terdiri dari karakteristik responden rumah tangga (keluarga yang diwawancara, usia, jenis kelamin, pekerjaan kepala keluarga, status pernikahan, jumlah anggota keluarga, jumlah pendapatan perbulan, dan asuransi kesehatan), merek obat, kekuatan sediaan, expired date, dan jumlah obat untuk mendata obat-obat yang disimpan oleh anggota rumah tangga, baik obat sebagai persediaan atau sedang digunakan, obat tidak digunakan dan obat kedaluwarsa serta mendata estimasi harga obat berdasarkan daftar harga produk obat tahun 2018 pada e-katalog Lembaga Kebijakan Pengadaan Barang/Jasa Pemerintah (LKPP) dan apotek swasta di Kota Yogyakarta. Validasi kuesioner dilakukan melalui uji content validity dengan melibatkan penilaian dari empat experts bidang farmasi komunitas dan dilakukan uji coba kuesioner kepada 20 responden rumah tangga non-sampel. Penelitian ini telah disetujui oleh komisi etik Fakultas Kedokteran Kesehatan Masyarakat dan Keperawatan Universitas Gadjah Mada dengan nomor KE/FK/0980/EC/2018. Data yang terkumpul kemudian dianalisis secara deskriptif untuk mengetahui frekuensi, persentase dan rata-rata.

\section{HASIL DAN PEMBAHASAN}

Studi estimasi biaya obat yang tidak digunakan baru pertama di Indonesia. Selama dua bulan penelitian dengan jumlah sampel 400 rumah tangga, terdiri dari $220 \mathrm{ibu}(55,0 \%)$, 16 anak $(4,0 \%)$, dan 89 ayah $(22,3 \%)$ sebagai responden dari perwakilan anggota keluarga. Mayoritas responden adalah perempuan $(63,7 \%)$, menikah $(72,0 \%)$, jumlah anggota keluarga 1 sampai 5 orang $(89,5 \%)$, rata-rata berusia 42 tahun, pekerjaan kepala keluarga sebagai wiraswasta (24,8\%), jumlah pendapatan < Rp2.000.000 (59,5\%), dan asuransi kesehatan dari program pemerintah (77,5\%) (Tabel I).

Abushanab (2012) dalam panelitiannya menemukan bahwa tingkat pendidikan, jumlah anggota keluarga, pendapatan dan anggota keluarga yang bekerja memiliki hubungan dengan jumlah obat yang disimpan di rumah. selain itu, adanya anggota keluarga yang mengalami penyakit kronis, dan anggota keluarga dengan tingkat pendidikan tinggi memiliki peluang yang sangat besar terhadap penyimpanan obat. Asuransi kesehatan juga menunjukkan adanya peluang bagi anggota keluarga untuk melakukan konsultasi kesehatan dan membeli atau diberi resep obat sehingga lebih sering menyimpan obat 
Tabel I. Distribusi karakteristik responden rumah tangga Kota Yogyakarta

\begin{tabular}{|c|c|}
\hline Variabel & Jumlah (\%) \\
\hline \multicolumn{2}{|c|}{ Keluarga yang diwawancarai } \\
\hline Ayah & $89(22,3)$ \\
\hline Ibu & $220(55,0)$ \\
\hline Anak & $16(4,0)$ \\
\hline \multicolumn{2}{|l|}{ Jenis kelamin } \\
\hline Laki-laki & $145(36,3)$ \\
\hline Perempuan & $255(63,7)$ \\
\hline \multicolumn{2}{|l|}{ Status pernikahan } \\
\hline Menikah & $288(72,0)$ \\
\hline Belum menikah & $90(22,5)$ \\
\hline Janda/duda & $22(5,5)$ \\
\hline \multicolumn{2}{|c|}{ Jumlah anggota keluarga } \\
\hline $1-5$ & $358(89,5)$ \\
\hline $6-10$ & $42(10,5)$ \\
\hline Usia (Mean, SD) & $42,22(15,1)$ \\
\hline \multicolumn{2}{|c|}{ Pekerjaan kepala keluarga } \\
\hline Tidak bekerja & $17(4,3)$ \\
\hline Buruh & $71(17,8)$ \\
\hline Swasta & $80(20,0)$ \\
\hline Wiraswasta & $99(24,8)$ \\
\hline Pedagang & $46(11,5)$ \\
\hline Pegawai swasta & $34(8,5)$ \\
\hline PNS & $31(7,8)$ \\
\hline Pensiunan & $22(5,5)$ \\
\hline \multicolumn{2}{|l|}{ Jumlah pendapatan (Rp) } \\
\hline$<2.000 .000$ & $238(59,5)$ \\
\hline $2.000 .000-5.000 .000$ & $136(34,0)$ \\
\hline $5.000 .000-10.000 .000$ & $23(5,8)$ \\
\hline$>10.000 .000$ & $3(0,8)$ \\
\hline \multicolumn{2}{|c|}{ Asuransi kesehatan yang dimiliki } \\
\hline Pemerintah & $310(77,5)$ \\
\hline Swasta & $23(5,8)$ \\
\hline Tidak ada & $70(17,5)$ \\
\hline
\end{tabular}

dirumah mereka daripada rumah tangga yang tidak mempunyai asuransi kesehatan. ${ }^{15,16}$

Selama periode penelitian, total responden yang menyimpan obat yaitu 261 $(65,2 \%)$ responden dengan total harga Rp7.082.556 yang dikelompokkan berdasarkan status obat yang disimpan terdiri dari obat yang sedang digunakan atau obat persediaan, obat tidak digunakan, dan obat kedaluwarsa. Estimasi harga obat pada penelitian ini berdasarkan pada $e$-katalog LKPP (Lembaga Kebijakan Pengadaan Barang/Jasa Pemerintah) dan layanan online apotek swasta sesuai harga produk tahun 2018 dengan total harga obat terbesar adalah obat yang sedang digunakan dan sebagai persediaan yaitu Rp5.668.570 atau $80 \%$ dari total harga obat dengan rata-rata per orang sebesar Rp25.419, sedangkan status obat tidak digunakan berharga Rp1.273.921 (18\%) 
Tabel II. Estimasi harga obat yang sedang digunakan dan sebagai persediaan, obat tidak digunakan dan obat kedaluwarsa pada kalangan rumah tangga di Kota Yogyakarta

\begin{tabular}{lccc}
\hline \multicolumn{1}{c}{ Status obat } & $\begin{array}{c}\text { Estimasi total harga } \\
\text { obat (Rp) }\end{array}$ & $\begin{array}{c}\text { Rata-rata harga } \\
\text { per orang (Rp) }\end{array}$ & Persentase (\%) \\
\hline Obat sedang digunakan dan & 5.668 .570 & 25.419 & 80 \\
persediaan (N=223) & 1.273 .921 & 13.698 & 18 \\
Obat tidak digunakan (N=93) & 140.065 & 12.733 & 2 \\
Obat kedaluwarsa (N=11) & 7.082 .556 & 21.659 & 100 \\
Total & & & \\
\hline
\end{tabular}

dengan rata-rata $\mathrm{Rp} 13.698$ dan obat kedaluwarsa berharga Rp140.065 (2\%) dengan rata-rata Rp12.733 per orangnya (Tabel II).

Jika dibandingkan dengan penelitian yang dilakukan di Amman Jordania, produk obat yang ditemukan dari 219 rumah tangga bernilai 15.510 Dinar Yordania (JD) dengan harga rata-rata produk obat tiap rumah tangga sebesar 70,82 Dolar Yordania, obat kedaluwarsa bernilai 1.464 Dinar Yordania, dan biaya obat tidak digunakan bernilai 2.558 Dinar Yordania (JD), serta obat dengan waktu kedaluwarsa tidak diketahui bernilai 225,85 Dinar Yordania. ${ }^{15}$ Di Amerika Serikat, dilaporkan bahwa dari 539 obat resep yang dilaporkan dari hasil survei fase I, harga obat resep yang tidak digunakan pada populasi di US memiliki harga sekitar 9.093 Dolar Amerika Serikat (USD) menggunakan Average Wholesale Price (AWP), dan pada hasil survei fase II dari 776 obat tidak digunakan yang terkumpul diperkirakan bernilai US\$ 123.965,89 Dolar Amerika Serikat (USD). ${ }^{8}$ Di Palestina, limbah obat dari 415 rumah tangga dengan persentase obat tidak digunakan, obat kedaluwarsa dan tanpa tanggal kedaluwarsa masing-masing yaitu 32,7\%, 17,7\%, dan $11 \%$ diperkirakan bernilai 16.100 Dolar Amerika Serikat (USD) dan secara nasional 19.000.000 Dolar Amerika Serikat (USD). Selain itu, obat yang sering terdapat pada kalangan rumah tangga adalah obat saluran pencernaan, muskuloskeletal, dan antiinfeksi. Sedangkan pada individu paling banyak ditemukan obat paracetamol $(8,5 \%)$, ibuprofen $(4,9 \%)$, dan diklofenak (3,7\%). ${ }^{17}$ Di Australia, estimasi harga obat kedaluwarsa atau tidak digunakan yang dikumpulkan per pasien dengan ratarata berharga 1.308 Dolar Australia (AUD) setiap tahun dan dari layanan apotek selama satu tahun dengan rata-rata 240 pasien diperkirakan obat kedaluwarsa atau tidak digunakan berharga sekitar 314.000 Dolar Australia (AUD) setiap tahunnya. ${ }^{18}$

Berdasarkan kelompok kelas terapi dan sistem tubuh, kelompok obat vitamin dan mineral dari obat sedang digunakan dan persediaan dengan estimasi total harga tertinggi bernilai Rp1.260.412, diikuti oleh kelompok sistem respirasi Rp910.420, sistem kardiovaskular Rp743.059, analgesik Rp704.659, dan sistem endokrin Rp497.811. Sedangkan harga tertinggi obat tidak digunakan terdapat pada kelompok obat analgesik dengan nilai sebesar Rp275.032, diikuti oleh sistem respirasi Rp273.884, antimikroba Rp200.132, vitamin dan mineral Rp144.612, kemudian saluran cerna dan entiemetik Rp118.595 selain itu terdapat obat kedaluwarsa dengan harga tertinggi yaitu pada kelompok terapi antiinflamasi dengan nilai Rp62.730 lalu diikuti antiseptik sebesar Rp40.468 dan analgesik Rp15.734 serta saluran cerna dan antiemetik Rp14.122 (Tabel III).

Dibandingkan dengan negara-negara lain sebagaimana penelitian yang dilakukan di Australia, kalkulasi harga obat dengan total harga tertinggi yaitu kelompok obat kardiovaskular sekitar 2.923 Dolar Australia (AUD), diikuti oleh psikotropik (1.326 Dolar Australia (AUD)), sistem respirasi dan analgesik (1.128 Dolar Australia (AUD))..$^{18} \mathrm{Di}$ Houston Texas, dilaporkan bahwa sebanyak 1.315 obat tidak digunakan yang terkumpul 
Tabel III. Jumlah dan estimasi harga obat yang sedang digunakan dan sebagai persediaan, obat tidak digunakan dan obat kedaluwarsa pada kalangan rumah tangga di Kota Yogyakarta berdasarkan sistem tubuh dan kelas terapi

\begin{tabular}{lccc}
\hline \multicolumn{4}{c}{ Obat sedang digunakan dan persediaan } \\
\hline $\begin{array}{c}\text { Kelompok obat berdasarkan kelas } \\
\text { terapi dan sistem tubuh }\end{array}$ & $\begin{array}{c}\text { Jumlah Kelompok } \\
\text { Obat Berdasarkan } \\
\text { Kelas Terapi dan } \\
\text { Sistem Tubuh(\%) }\end{array}$ & Harga (Rp) & $\begin{array}{c}\text { Persentase } \\
\text { Harga (\%) }\end{array}$ \\
\hline vitamin dan mineral & $45(8,8)$ & 1.260 .412 & 22,2 \\
sistem respirasi & $89(17,4)$ & 910.420 & 16,1 \\
sistem kardiovaskular & $84(16,4)$ & 743.059 & 13,1 \\
Analgesik & $161(31,5)$ & 704.659 & 12,4 \\
sistem endokrin & $28(5,5)$ & 497.811 & 8,8 \\
Obat tidak digunakan atau obat sisa & & & \\
Analgesik & $65(28,6)$ & 275.032 & 21,6 \\
sistem respirasi & $31(13,7)$ & 273.884 & 21,5 \\
Antimikroba & $27(11,9)$ & 200.132 & 15,7 \\
vitamin dan mineral & $18(7,9)$ & 144.612 & 11,4 \\
$\quad$ saluran cerna dan antiemetik & $29(12,8)$ & 118.595 & 9,3 \\
Obat kedaluwarsa & & & \\
Antiinflamasi & $2(12,5)$ & 62.730 & 44,8 \\
Antiseptik & $3(18,8)$ & 40.468 & 28,9 \\
Analgesik & $3(18,8)$ & 15.734 & 11,2 \\
saluran cerna dan antiemetik & $3(18,8)$ & 14.122 & 10,1 \\
\hline
\end{tabular}

selama enam bulan penelitian terdapat obat antiinflamasi/antinyeri $(25 \%)$, antihistamin $(15 \%)$, antiinfeksi $(11 \%)$, kardiovaskular $(7 \%)$, pernapasan $(9 \%)$, neurologi $(8 \%)$, dermatologi (7\%), dan gastrointestinal (7\%), bernilai 26.222 Dolar berdasarkan harga dari red book $2001 .^{19}$ Di Kairo, obat yang terkumpul dari pengembalian pasien dilaporkan sebanyak 541 item obat dengan total harga sebesar 10.988,84 Egyptian pounds (EGP) terdiri dari antibiotik (20,15\%), Gastrointestinal (16,27\%), sistem kardivaskular $(10,72 \%)$, dan sistem pernapasan $(8,13 \%)$, dengan alasan kondisi membaik, pasien meninggal, obat kedaluwarsa dan perubahan obat yang diresepkan. ${ }^{2}$ Di Amman Jordan, berdasarkan survey pada rumah tangga dengan total 219 responden memiliki total 2.393 produk obat atau rata-rata memiliki 10,9 produk obat setiap rumah tangga, terdiri dari $(15 \%)$ obat tidak digunakan, $(10,9 \%)$ obat kedaluwarsan, dan $(1,8 \%)$ tidak jelas tanggal kedaluwarsanya.
Selain itu, obat yang disimpan secara per orangan utamanya obat paracetamol $(8,4 \%)$, diklofenak $(4,1 \%)$, dan amoxicillin $(3,3 \%)$. Berdasarkan hal tersebut, diperkiran total nilai obat yang terbuang yaitu sebesar 3791 Dinar Yordania (JD) atau setara 5.414 Dolar Amerika Serikat (USD). ${ }^{15}$

Estimasi biaya obat yang tidak digunakan dalam penelitian ini dapat menunjukkan hasil yang berbeda jika lokasi wilayah diperluas atau pengaturan lokasi seperti di pelayanan kesehatan yakni rumah sakit, apotek, klinik, dan pelayanan kesehatan lainnya. Jika berdasarkan hasil riset kesehatan dasar tahun 2013 di Indonesia yang melaporkan bahwa 103.860 rumah tangga menyimpan obat. Berdasarkan status obat yang disimpan terdapat $48.814(47 \%)$ rumah tangga menyimpan obat sisa. ${ }^{20}$ Jika jumlah rumah tangga yang menyimpan obat sisa dikalikan dengan harga rata-rata obat tidak digunakan per orang dalam rumah tangga 
sebesar Rp13.698 pada penelitian ini maka nilai ekonomi obat tidak digunakan yang bisa dihemat atau tidak terbuang sia-sia bernilai Rp668.654.172.

Terlepas dari dimensi ekonomi, Kristina dkk. dalam penelitian yang dilakukan di Yogyakarta mengemukakan beberapa alasan obat yang tidak digunakan oleh responden karena merasa kondisinya telah membaik, kondisi tidak membaik dengan penggunaan obat tertentu, perubahan resep atau penghentian penggunaan obat dari dokter, mengalami efek samping, dan berubah kepengobatan herbal atau tradisional. ${ }^{21}$ Bagaimanapun juga, penghentian terapi menunjukkan sejumlah besar biaya obat yang terbuang sia-sia. Oleh karena itu diperlukan minimalisasi obat yang tidak digunakan. ${ }^{22}$ Selain itu dalam penelitian ini ditemukan beberapa masalah yang berkaitan dengan kepatuhan penggunaan obat utamanya pada obat antimikroba tidak digunakan maupun tidak dihabiskan sehingga berpotensi mengakibatkan resistensi. Adanya obat antibiotik yang tidak digunakan menunjukkan hasil ketidak patuhan terhadap antibiotik yang diresepkan, peresepan yang berlebih atau hasil dari pengobatan sendiri. ${ }^{21}$ selain itu, terdapat pula obat tidak digunakan atau obat sisa dalam kelas terapi sistem saraf pusat yang berpotensi terhadap penyalahgunaan obat. Dalam penelitian ini pula ditemukan obat-obat kedaluwarsa yang masih disimpan sehingga dapat beresiko terhadap penggunasalahan obat dan memperburuk kondisi kesehatan akibat efek negatif dari produk obat yang telah kedaluwarsa.

Kombinasi manajemen terapi pengobatan dan edukasi untuk meningkatkan kesadaran masyarakat dapat mengurangi limbah obat dan juga meningkatkan penggunaan obat-obat secara baik atau rasional. Selain itu juga dapat mengurangi biaya dengan meningkatkan hasil kesehatan melalui kepatuhan sehingga efisiensi dalam sistem perawatan kesehatan juga meningkat. ${ }^{8}$

\section{KESIMPULAN}

Penelitian ini memiliki beberapa keterbatasan. Pertama, sampel terbatas hanya pada bagian wilayah Kota Yogyakarta. Kedua, estimasi biaya obat pada penelitian ini berdasarkan harga produk obat e-katalog LKPP tahun 2018 dan layanan online apotek swasta di Kota Yogyakarta sehingga memungkinkan adanya perbedaan harga pada daerah tertentu di Indonesia atau dari sumber-sumber katalog harga produk obat yang lain.

\section{UCAPAN TERIMA KASIH}

Ucapan terima kasih kepada pembimbing utama dan pendamping yang telah memberikan masukan, kritik dan saran dalam penulisan artikel penelitian kami dan kepada Fakultas Farmasi Universitas Gadjah Mada, Yogyakarta.

\section{DAFTAR PUSTAKA}

1. Vogler S., de Rooij RHPF. Medication wasted - Contents and costs of medicines ending up in household garbage. Res Soc Adm Pharm. 2018;14(12):1140-1146.

2. El-hamamsy M., El-hamamsy APM., Pharmacy F. Unused Medications: How Cost and How Disposal of in Cairo, Egypt. Int J Pharm Stud Res. 2011;2(1):21-27.

3. Ruhoy IS., Daughton CG. Beyond the medicine cabinet: An analysis of where and why medications accumulate. Environ Int. 2008;34(8):1157-1169.

4. Abahussain E., Waheedi M., Koshy S. Practice., awareness and opinion of pharmacists toward disposal of unwanted medications in Kuwait. Saudi Pharm J. 2012;20(3):195-201.

5. Braund R., Chuah F., Gilbert R., Gn G., Soh A., Tan LY. Identification of the reasons for medication returns Original Scientific Papers Original. 2008;35(4):248-252.

6. WHO. Safe Management of Wastes from Health-Care Activities a Summary. 
Geneva; 2017.

7. AlSamanhodi H., Almeshary M., Amoh K., et al.,. Evaluation of the causes and cost impact of returned intravenous medications at a tertiary care hospital in Riyadh, Saudi Arabia. Trop J Pharm Res. 2017;16(1):231-237.

8. Law A V., Sakharkar P., Zargarzadeh A., et al., Taking stock of medication wastage: Unused medications in US households. Res Soc Adm Pharm. 2015;11(4):571-578.

9. Al-Azzam S., Khader Y., Rawashdeh S., Hijazi S. An assessment of the extent of medication wastage among families in Jordan. Jordan J Pharm Sci. 2012;5(1):6573.

10. Barnett-itzhaki Z., Berman T., Grotto I., Schwartzberg E. Household medical waste disposal policy in Israel. Isr J Health Policy Res. 2016:1-8.

11. Jarvis CI., Seed SM., Silva M., Sullivan KM. Educational Campaign for Proper Medication Disposal. J Am Pharm Assoc. 2009:65-68.

12. Doble B., Payne R., Harshfield A., Wilson ECF. Retrospective, multicohort analysis of the Clinical Practice Research Datalink (CPRD) to determine differences in the cost of medication wastage., dispensing fees and prescriber time of issuing either short ( $<60$ days) or long ( $\geq 60$ days) prescription length. BMJ Open. 2017;7(12).

13. Badan Pusat Statistik. Kota Yogyakarta Dalam Angka. Yogyakarta: Badan Pusat Statistik Kota Yogyakarta; 2017.

14. Notoatmodjo S. Metodologi Penelitian Kesehatan. Jakarta: Rineka Cipta; 2005.

15. Abushanab AS., Sweileh WM., Wazaify M. Storage and wastage of drug products in Jordanian households: a cross-sectional survey. Int J Pharm Pract.
2013;21(3):185-191.

16. Teni FS., Surur AS., Belay A., et al., A household survey of medicine storage practices in Gondar town , northwestern Ethiopia. 2017:1-9.

17. Sweileh WM., Sawalha AF., Zyoud ed H., Al-Jabi SW., Bani Shamseh FF., Sh Khalaf H. Storage., Utilization and Cost of Drug Products in Palestinian Households Running Title: Drug Products in Palestinian Households Storage, Utilization and Cost of Drug Products in Palestinian Households. 2013:1-25.

https://pdfs.semanticscholar.org/c346/c 4a606c3204ce306f7f48cdeef4746de9fc4. pdf.

18. Guirguis K. Medications collected for disposal by outreach pharmacists in Australia. Pharm World Sci. 2010;32(1):52-58.

19. Garey KW., Johle ML., Behrman K., Neuhauser MM. Economic consequences of unused medications in Houston, Texas. Ann Pharmacother. 2004;38(7-8):1165-1168.

20. Kemenkes. Riset Kesehatan Dasar. Jakarta; 2013.

21. Kristina SA., Wiedyaningsih C., Cahyadi A., Ridwan BA. A Survey on Medicine Disposal Practice among Households in Yogyakarta. Asian J Pharm. 2018;2018(3):955-958.

22. Bekker CL., Melis EJ., Egberts ACG, Bouvy ML, Gardarsdottir H, Van Den Bemt BJF. Quantity and economic value of unused oral anti-cancer and biological disease-modifying antirheumatic drugs among outpatient pharmacy patients who discontinue therapy. Res Soc Adm Pharm. 2019;15(1):100-105. 